\title{
12. ILEŠIČEVI DNEVI - SEMINAR STALNEGA STROKOVNEGA SPOPOLNJEVANJA UČITELJEV GEOGRAFIJE
}

12. Ilešičevi dnevi so potekali v času od 27. do 29. 9. 2001 na Filozofski fakulteti v Ljubljani. Udeležilo se jih je 108 udeležencev, med katerimi so prevladovali učitelji geografije, medtem ko je s predavanji, delavnicami ter ekskurzijami sodelovalo 24 predavateljev.

Prevladovali so trije vsebinski sklopi:

- Slovenija v dobi globalizacije,

- interdisciplinarnost pri pouku geografije,

- $\quad$ novi pristopi k poučevanju geografije.

$\mathrm{Na}$ te sklope so se v večji ali manjši meri nanašala predavanja in delavnice, medtem ko sta bili obe ekskurziji organizirani z vidika aktualnosti (Log pod Mangartom) oz. geografske zanimivosti (Otlica - Paradana - Smrekova Draga).

Prvi dan je bil namenjen predavanjem in delavnicam s poudarkom na strokovnem in osebnostnem razvoju učitelja geografije v vseh življenjskih obdobjih, pri čemer je J. Kunaver posebej poudaril tretje življenjsko obdobje oz. zadnjo triado delovne dobe učiteljev. V nadaljevanju so I. Lipovšek, N. Cigler, K. Cunder, T. Resnik Planinc, M. Umek in S. Popit govorili o položaju šolske geografije po kurikularnih spremembah, o potrebnih spremembah v učnih načrtih, o vključevanju geografije v mednarodne projekte ter o vprašanjih zakaj, kaj in kako poučevati geografijo. K. Kolenc Kolnik se je osredotočila na možnosti korelacije geografije z ostalimi šolskimi predmeti. M. M. Klemenčič, M. Pak in A. Gosar so osvetlili položaj Slovenije v dobi globalizacije, regionalni razvoj Slovenije in se spraševali o primerjavah ameriškega in evropskega sna. V dopoldanskem času smo odprli razstavo »Peru - po poteh Inkovske civilizacije«, v popoldanskem času je ZGDS podelila priznanja, v večernih urah, po zaključku predavanj, pa je imelo Društvo učiteljev geografije Slovenije občni zbor s podelitvijo priznanj.

Drugi dan je potekalo 9 različnih delavnic (nekatere so se zaradi velikega zanimanja izvajale $2 \mathrm{x}$ ) na teme: virtualna geografija, analiza slikovnih gradiv za razlago pokrajine pri pouku geografije, terensko delo kot del priprave na maturo, eksperiment pri pouku geografije, interdisciplinarnost v OŠ na primeru ekskurzije, ekonomsko geografske teme pri pouku geografije, portfolio - nova učna metoda in filozofija poučevanja, slovensko podeželje - izbrani primeri za potrebe pouka geografije ter izvedba učnih ur z interdisciplinarno vsebino.

Tretji dan smo organizirali dve celodnevni ekskurziji, ki sta bili med udeleženci zelo dobro sprejeti:

- Ljubljana- Godovič - Col - Sinji vrh - Otlica - Paradana - Smrekova Draga -Ljubljana,

- $\quad$ Ljubljana- Rateče - Trbiž - Predel -Log pod Mangartom - Bovec - Tolmin -Ljubljana.

Prispevki s 12. Ilešičevih dnevov so bili objavljeni v Geografiji v šoli.

Tatjana Resnik Planinc 